\title{
加工時のゼオライト処理による梅漬け中の放射性セシウム含量の低減
}

\author{
関澤春仁 *・丹治克男・吉岡邦雄 \\ 福島県農業総合センター 963-0531＼cjkstart福島県郡山市日和田町高倉字下中道
}

\section{Reduction of Radioactive Cesium Content of Pickled Plum by Zeolite Treatment during Processing}

\author{
Haruhito Sekizawa*, Katsuo Tanji and Kunio Yoshioka \\ Fukushima Agricultural Technology Centre, Simonakamichi, Takakura, Hiwada, Koriyama, Fukushima 963-0531
}

\begin{abstract}
Zeolite, a designated food additive, is known to absorb radioactive cesium via its cation exchange ability. In this study, we investigated the effects of zeolite treatment on the removal of radioactive cesium from flesh of the pickled plum during the production process, and found that the concentration of radioactive cesium in the flesh was reduced by the addition of zeolite. Taking the concentration of radioactive cesium in the pickled plum in the absence of zeolite as $100 \%$, that in the presence of $10 \%$ zeolite was $55 \%$, and that in the presence of $20 \%$ zeolite was $54 \%$. On the other hand, the concentration of radioactive cesium was $74 \%$ when $10 \%$ granulated zeolite was added. Furthermore, when processed with brine, the radioactive cesium concentration was reduced to $31 \%$ by adding $10 \%$ zeolite.
\end{abstract}

Key Words : processing of plum, radioactive material

キーワード：放射性物質，梅漬け

\section{緒 言}

2011 年 3 月の東日本大震災に伴って発生した東京電力 福島第一原子力発電所の事故に対し，福島県をはじめとす る各自治体では農林水産物のモニタリング検査や加工食品 などの放射性物質検査を実施して国の定める放射性物質の 基準值を超える食品の流通を防ぐ対策が取られている.

福島県に扣ける果実のモニタリング調査結果によると, 2011 年度は, 検査総数 1426 点のらち暫定規制值を超えた ものが全体の $1.8 \%$ であり, その後設定された一般の食品 の基準值を適用した場合は全体の 12.6\%が基準值を超える 值であった。しかし，2012 年度では検査総数 1463 点のら ち一般の食品の基準值を超えたものは 4 点のみであり，検 査総数の $0.27 \%$ と大きく減少した（厚生労働省，2013）.

果実が放射性セシウムによって污染される経路は, 放射 性降下物による直接污染のほか, 污染された樹皮や葉から の転流, 污染された土壌からの経根吸収があり, その詳細 についても明らかにされてきている（高田ら，2012; 高田 ら，2013）。これらの報告や，今までの農産物のモニタリ ング検査の結果から, 今後果実の放射性セシウムはさらに

2014 年 4 月 11 日 受付. 2014 年 9 月 11 日 受理.

* Corresponding author. E-mail: sekizawa_haruhito_01@pref.fukushima. $\lg . j p$
減少すると考えられるが，人工核種である放射性セシウム の存在は基準值内であっても消費者の関心が高く, 食品中 の放射性セシウムをできる限り少なくすることが求められ ている.

放射性物質と食品加工に関する研究は，1986 年に発生 したチェルノブイリ原子力発電所事故の後に多く報告され ている（財団法人原子力環境整備センター，1994）が，福 島第一原子力発電所の事故に関しても既に様々な報告が されている (Goto ら，2014; 八戸ら，2013; 八戸ら，2014; Kimura ら，2012; 鍋師ら，2013; 関澤ら，2013; Tagami ら， 2013; 等々力ら，2013）。農産物に含まれる放射性七シウム は加工によって消失することはないが，乾燥による濃縮， 水煮などによる流出，浸漬による滲出や滲入など，農産物 の内外へは容易に移動する。そこで我々は，より積極的に 放射性セシウムを低減するため,「ゼオライト」の加工利 用に着目した.

ゼオライトは多孔質の骨格を持つ鉱物の一種で，陽イオ ン交換作用や吸湿，吸着作用などの特徵を持っており，農 地の土壤改良や家畜の飼料添加物, 工場の排水処理などに 幅広く用いられ，放射性物質による污染水や土壤の放射性 セシウムの吸着などにも利用されている.

一方, 食品への利用に関しては厚生労働省の既存添加物 名簿に製造用剂として記載されており（厚生省，1996）, 一般食品に対し最大残存量が $0.5 \%$ 以下で，かつ食品製造 
または加工上必要不可欠な場合に限り利用が可能とされて いる（厚生省，1959）.

ゼオライトを用いて食品の放射性セシウムを低減する場 合, ゼオライトを食品に接触させる必要があるため, 対象 となる食品は液体である必要がある。我々は既にリンゴ ジュースのゼオライト処理について検討を行い, 放射性セ シウムを低減できることを明らかにしている（関澤ら, 2013). 一方, 梅漬けの加工に拈いては, 果汁が漬け汁と して滲出するため, 加工中のゼオライト処理が可能である と考号れる。 また, ウメは農産物のモニタリング検査で 検出される放射性セシウム濃度が他の果実よりも総じて高 い傾向があり, 自家加工も多い果実である. そこで本研究 では，簡易に放射性セシウムを低減する方法として梅漬け 加工時のゼオライト添加処理について検討を行ったので報 告する.

\section{材料および方法}

\section{1. 材料}

\section{1）果実原料}

原料には 2013 年 6 月に福島県内の空間線量が比較的高 い地域で収穫された小梅（品種不明, 平均 1 果重 $3.13 \mathrm{~g}$ ) を用いた。

\section{2）供試資材}

実験には山形県米沢市板谷地区から産出されたゼオライ ト（ジークライト（株)）を用いた。 このゼオライトはク リノプチロライトに少量のモルデナイトを含んで拈り, セ シウムイオンの吸着能力についてb確認されている（日本 原子力学会バックエンド部会, 2011).

ゼオライトを粒径 $1 \sim 3 \mathrm{~mm}$ 程度に破砕・焼成したもの を「ゼオライト」, ゼオライトを粉末化した後に粒径 3 $5 \mathrm{~mm}$ に造粒・焼成したものを「造粒ゼオライト」として 用いた。 な打，余分な粉末や不純物等を除去するため，実 験に使用する前に $1 \mathrm{~kg}$ 当たり約 $5 \mathrm{~L}$ の蒸留水で洗浄し, これを20回繰り返した. その後, $105^{\circ} \mathrm{C}$ に設定した乾燥 機で 18 時間乾燥させて実験に用いた。

\section{2. 加工方法}

梅漬け加工は，プラスチック製の漬物樽に，よく洗浄し たウメ $1000 \mathrm{~g}$ と食塩 $200 \mathrm{~g}$ を入れ，2000 g の重しを乗せて 1 か月間 $15^{\circ} \mathrm{C}$ で加工した. ゼオライトを添加しない区を「ス
タンダード」とし，ゼオライト添加区に打いては，不織布 の袋に入れたゼオライトをウメ重量の $10 \% ， 20 \%$ たは 造粒ゼオライトを $10 \%$ ，それぞれ加工時に一緒に漬け込 んだものを「ゼオライト 10\%区」「ゼオライト 20\%区」「造 粒ゼオライト $10 \%$ 区」とした，さらに，加工時に食塩 $20 \%$ 濃度の塩水をウメと等重量加えて浸漬した区を「ゼオ ライト $10 \%$ 塩水区」とした。

加工はそれぞれ 3 反復行った.

\section{3. 放射性物質の測定方法}

原料と加工後の果肉および種はミキサーで破砕し, 加工 後の漬け汁はそのままU8 型のプラスチック製のねじ口容 器に充填した。 また, 加工後のゼオライトは乾燥機で乾燥 させた後にU-8 容器に充填し, ゲルマニウム半導体検出 器を用いたガンマ線スペクトロメータ（GC3020-7500SL$2002 \mathrm{CSL}$ ，キャンベラジャパン）を用いて ${ }^{134} \mathrm{Cs}$ と ${ }^{137} \mathrm{Cs}$ の 濃度を測定し, それらの合計值を放射性セシウム濃度とし た. 測定時間は 3600 秒で行い, 濃度が $20 \mathrm{~Bq} \cdot \mathrm{kg}^{-1}$ 以下 のサンプルについては 36000 秒で再測定を行った.

\section{4. 統計解析}

加工前後の重量と放射性セシウム濃度については 3 反復 の平均值を求めた，有意差検定は統計ソフトJSTATを用 いて Tukey 法で行い, 有意水準は危険率 5\%未満とした.

\section{結果}

\section{1. 重量の変化}

加工後の果実重量と果肉重量をスタンダード区と比較す ると，ゼオライト $10 \%$ 区，ゼオライト $20 \%$ 区，造粒ゼオ ライト $10 \%$ 区ではいずれも有意に減少した(第1表).一方, ゼオライト $10 \%$ 塩水区に扣いては加工後も原料とほぼ同 じ重量であった。種に拈いては，ゼオライト20\%区だけ がスタンダード区よりも有意に重量が大きかったが，その 差は大きいものではなかった，漬け汁に打いては，加工条 件が異なるゼオライト $10 \%$ 塩水区を除くと，スタンダー ド区のみがその他のゼオライトを添加した区よりも有意に 少なかった。

\section{2. 果肉の放射性セシウム濃度の变化}

果肉の放射性セシウム濃度は, 原料果肉では $70.6 \mathrm{~Bq} ・$ $\mathrm{kg}^{-1}$ であったが，スタンダード区では $55.6 \mathrm{~Bq} \cdot \mathrm{kg}^{-1}$ となり， 通常の梅漬け加工によって放射性セシウム濃度は減少した

第 1 表 加工前後の重量変化

\begin{tabular}{|c|c|c|c|c|}
\hline 試験区 & 果実全体 z （g） & 果肉 ${ }^{\mathrm{z}}(\mathrm{g})$ & 種 $\mathrm{z}(\mathrm{g})$ & 漬け汁 ${ }^{\mathrm{z}}(\mathrm{g})$ \\
\hline 原料ウメ & $1000 \pm 0$ & $776 \pm 2$ & $224 \pm 2$ & - \\
\hline スタンダード & $775 \pm 7 b$ & $545 \pm 4 b$ & $230 \pm 4 \mathrm{c}$ & $425 \pm 7 \mathrm{c}$ \\
\hline ゼオライト 10\% & $708 \pm 10 \mathrm{c}$ & $461 \pm 11 \mathrm{c}$ & $247 \pm 3 \mathrm{ac}$ & $474 \pm 11 \mathrm{~b}$ \\
\hline ゼオライト 20\% & $684 \pm 9 \mathrm{c}$ & $432 \pm 9 c$ & $252 \pm 1 \mathrm{ab}$ & $480 \pm 9 b$ \\
\hline 造粒ゼオライト $10 \%$ & $704 \pm 5 \mathrm{c}$ & $457 \pm 6 \mathrm{c}$ & $247 \pm 4 \mathrm{bc}$ & $484 \pm 5 b$ \\
\hline ゼオライト $10 \%$ 塩水 & $998 \pm 7 a$ & $760 \pm 4 a$ & $239 \pm 5 \mathrm{bc}$ & $996 \pm 7 \mathrm{a}$ \\
\hline
\end{tabular}

$\mathrm{z}$ 平均 \pm 標準誤差 $(\mathrm{n}=3)$ ，異符号間には Tukey の方法 $(\mathrm{P}<0.05, \mathrm{n}=3)$ で有意差あり 
(第 2 表)。また，スタンダード区と比較した場合，ゼオラ イトを添加した区に执いてはすべての区で放射性セシウム 濃度が有意に低くなっていた。 ゼオライト $10 \%$ 区は $30.5 \mathrm{~Bq} \cdot \mathrm{kg}^{-1}$, ゼオライト $20 \%$ 区では $30.2 \mathrm{~Bq} \cdot \mathrm{kg}^{-1}$ となり, ゼオライトの添加量が異なっても放射性セシウム濃度に有 意差はなかった。 また，造粒ゼオライト $10 \%$ 区では $41.2 \mathrm{~Bq} \cdot \mathrm{kg}^{-1}$ となり，ゼオライト $10 \%$ 区よりも放射性セ シウム濃度は有意に高く, ゼオライトの形状によって差が あることが確認された. 一方，ゼオライト $10 \%$ 塩水区で は $17.2 \mathrm{~Bq} \cdot \mathrm{kg}^{-1}$ となり, 試験したすべての区で最も低い 值を示した。

また，スタンダード区の放射性セシウム濃度を $100 \%$ と した場合の各試験区の放射性セシウム濃度比を計算する と，ゼオライト 10\%区では 55\%，ゼオライト $20 \%$ 区では 54\%，造粒ゼオライト 10\%区では74\%，ゼオライト $10 \%$ 塩水区では $31 \%$ とった。

\section{3. 種の放射性セシウム濃度}

種に含まれる放射性セシウム濃度は，スタンダード区で は $35.1 \mathrm{~Bq} ・ \mathrm{~kg}^{-1}$ となり，原料ウメの $35.0 \mathrm{~Bq} \cdot \mathrm{kg}^{-1}$ とほぼ 同じ濃度であった（第 3 表）。また，スタンダード区と比 較した場合，ゼオライトを添加した区に打いてはすべての 区で放射性セシウム濃度が有意に減少していた。 ゼオライ ト $10 \%$ 区では $24.2 \mathrm{~Bq} \cdot \mathrm{kg}^{-1}$ ， ゼオライト $20 \%$ 区では $19.7 \mathrm{~Bq} \cdot \mathrm{kg}^{-1}$ となったが，この 2 区間に有意差はなかった. また，造粒ゼオライト $10 \%$ 区では $27.5 \mathrm{~Bq} ・ \mathrm{~kg}^{-1}$ となり， ゼオライト $10 \%$ 区と有意差はなく，ゼオライトの形状に よる差は確認されなかった。 一方，ゼオライト $10 \%$ 塩水 区では $12.7 \mathrm{~Bq} \cdot \mathrm{kg}^{-1}$ となり，試験区の中で最も低い值を 示した.

また，スタンダード区の放射性セシウム濃度を $100 \%$ と した場合の各試験区の放射性セシウム濃度比を計算する と，ゼオライト 10\%区では 69\%，ゼオライト 20\%区では

第 2 表 梅漬け (果肉) の放射性セシウム濃度

\begin{tabular}{|c|c|c|c|c|}
\hline 試験区 & $\begin{array}{l}{ }^{134} \mathrm{Cs} \text { 濃度 } \\
\left(\mathrm{Bq} \cdot \mathrm{kg}^{-1}\right)\end{array}$ & $\begin{array}{l}{ }^{137} \mathrm{Cs} \text { 濃度 } \\
\left(\mathrm{Bq} \cdot \mathrm{kg}^{-1}\right)\end{array}$ & $\begin{array}{c}\text { 放射性セシウム濃度 } \mathrm{z}, \mathrm{y} \\
\left(\mathrm{Bq} \cdot \mathrm{kg}^{-1}\right)\end{array}$ & $\begin{array}{c}\text { 放射性セシウム濃度比 } \mathrm{x} \\
(\%)\end{array}$ \\
\hline 原料ウメ & $22.8 \pm 1.5$ & $47.8 \pm 5.7$ & $70.6 \pm 5.9$ & - \\
\hline スタンダード & $18.1 \pm 1.1$ & $37.5 \pm 1.7$ & $55.6 \pm 2.0 \mathrm{a}$ & 100 \\
\hline ゼオライト 10\% & $9.7 \pm 0.2$ & $20.8 \pm 0.3$ & $30.5 \pm 0.3 \mathrm{c}$ & 55 \\
\hline ゼオライト $20 \%$ & $10.3 \pm 0.6$ & $19.9 \pm 1.3$ & $30.2 \pm 1.5 \mathrm{c}$ & 54 \\
\hline 造粒ゼオライト $10 \%$ & $13.6 \pm 0.4$ & $27.6 \pm 1.3$ & $41.2 \pm 1.4 \mathrm{~b}$ & 74 \\
\hline ゼオライト $10 \%$ 塩水 & $5.8 \pm 0.1$ & $11.4 \pm 0.1$ & $17.2 \pm 0.2 \mathrm{~d}$ & 31 \\
\hline
\end{tabular}

${ }^{\mathrm{z}}{ }^{134} \mathrm{Cs}$ 濃度と ${ }^{137} \mathrm{Cs}$ 濃度の合計を放射性セシウム濃度とした

$\mathrm{y}$ 平均 \pm 標準䛊差 $(\mathrm{n}=3)$ ，異符号間には Tukey の方法（ $\mathrm{P}<0.05, \mathrm{n}=3)$ で有意差あり

$\mathrm{x}$ スタンダード区を 100 とした場合の濃度比

第 3 表 梅漬け（種）の放射性セシウム濃度

\begin{tabular}{|c|c|c|c|c|}
\hline 試験区 & $\begin{array}{l}{ }^{134} \mathrm{Cs} \text { 濃度 } \\
\left(\mathrm{Bq} \cdot \mathrm{kg}^{-1}\right)\end{array}$ & $\begin{array}{l}{ }^{137} \mathrm{Cs} \text { 濃度 } \\
\left(\mathrm{Bq} \cdot \mathrm{kg}^{-1}\right)\end{array}$ & $\begin{array}{c}\text { 放射性セシウム濃度 } \mathrm{z} \\
\left(\mathrm{Bq} \cdot \mathrm{kg}^{-1}\right)\end{array}$ & $\begin{array}{c}\text { 放射性セシウム濃度比 }{ }^{\mathrm{y}} \\
(\%)\end{array}$ \\
\hline 原料ウメ & $9.6 \pm 1.1$ & $25.4 \pm 1.3$ & $35.0 \pm 1.8$ & - \\
\hline スタンダード & $10.9 \pm 0.5$ & $24.2 \pm 1.6$ & $35.1 \pm 1.7 \mathrm{a}$ & 100 \\
\hline ゼオライト 10\% & $8.0 \pm 0.9$ & $16.2 \pm 0.9$ & $24.2 \pm 1.3 \mathrm{bc}$ & 69 \\
\hline ゼオライト 20\% & $6.3 \pm 0.5$ & $13.3 \pm 0.4$ & $19.7 \pm 0.6 \mathrm{c}$ & 56 \\
\hline 造粒ゼオライト $10 \%$ & $9.3 \pm 0.5$ & $18.2 \pm 0.3$ & $27.5 \pm 0.6 \mathrm{~b}$ & 78 \\
\hline ゼオライト 10\%塩水 & $4.0 \pm 0.3$ & $8.7 \pm 0.2$ & $12.7 \pm 0.4 \mathrm{~d}$ & 36 \\
\hline
\end{tabular}

$\mathrm{z}$ 平均 \pm 標準誤差 $(\mathrm{n}=3)$ ，異符号間には Tukey の方法 $(\mathrm{P}<0.05, \mathrm{n}=3)$ で有意差あり

y スタンダード区を 100 とした場合の濃度比

第 4 表 漬け汁の放射性セシウム濃度

\begin{tabular}{|c|c|c|c|c|}
\hline 試験区 & $\begin{array}{l}{ }^{134} \mathrm{Cs} \text { 濃度 } \\
\left(\mathrm{Bq} \cdot \mathrm{kg}^{-1}\right)\end{array}$ & $\begin{array}{l}{ }^{137} \mathrm{Cs} \text { 濃度 } \\
\left(\mathrm{Bq} \cdot \mathrm{kg}^{-1}\right)\end{array}$ & $\begin{array}{c}\text { 放射性セシウム濃度 } \mathrm{z} \\
\left(\mathrm{Bq} \cdot \mathrm{kg}^{-1}\right)\end{array}$ & $\begin{array}{c}\text { 放射性セシウム濃度比 } \mathrm{y} \\
(\%)\end{array}$ \\
\hline スタンダード & $19.8 \pm 1.8$ & $40.3 \pm 2.6$ & $60.1 \pm 3.2 \mathrm{a}$ & 100 \\
\hline ゼオライト 10\% & $12.2 \pm 1.4$ & $21.0 \pm 1.1$ & $33.2 \pm 1.8 \mathrm{bc}$ & 55 \\
\hline ゼオライト 20\% & $9.2 \pm 0.4$ & $17.5 \pm 0.7$ & $26.7 \pm 0.8 \mathrm{c}$ & 48 \\
\hline 造粒ゼオライト $10 \%$ & $12.2 \pm 0.8$ & $26.1 \pm 2.7$ & $38.3 \pm 2.8 \mathrm{~b}$ & 64 \\
\hline ゼオライト 10\%塩水 & $5.5 \pm 0.3$ & $11.5 \pm 0.3$ & $17.0 \pm 0.4 \mathrm{~d}$ & 28 \\
\hline
\end{tabular}

$\mathrm{z}$ 平均 \pm 標準誤差 $(\mathrm{n}=3)$ ，異符号間には Tukey の方法（P<0.05, $\mathrm{n}=3)$ で有意差あり

y スタンダード区を 100 とした場合の濃度比 
第 5 表 ゼオライトの放射性セシウム濃度

\begin{tabular}{cccc}
\hline \hline 試験区 & $\begin{array}{c}{ }^{134} \mathrm{Cs} \text { 濃度 } \\
\left(\mathrm{Bq} \cdot \mathrm{kg}^{-1}\right)\end{array}$ & $\begin{array}{c}{ }^{137} \mathrm{Cs} \text { 濃度 } \\
\left(\mathrm{Bq} \cdot \mathrm{kg}^{-1}\right)\end{array}$ & $\begin{array}{c}\text { 放射性セシウム濃度 } \\
\left(\mathrm{Bq} \cdot \mathrm{kg}^{-1}\right)\end{array}$ \\
\hline 処理前のゼオライト & $5.5 \pm 0.2$ & $6.8 \pm 0.2$ & $12.3 \pm 0.3$ \\
処理前の造粒ゼオライト & $2.8 \pm 0.1$ & $1.0 \pm 0.0$ & $3.8 \pm 0.1$ \\
\hline ゼオライト $10 \%$ & $84.1 \pm 3.4$ & $188.0 \pm 4.8$ & $272.1 \pm 5.9 \mathrm{~b}$ \\
ゼオライト $20 \%$ & $57.5 \pm 1.1$ & $118.0 \pm 3.2$ & $175.5 \pm 3.4 \mathrm{c}$ \\
造粒ゼオライト 10\% & $65.4 \pm 5.0$ & $128.0 \pm 2.9$ & $3.4 \pm 5.8 \mathrm{c}$ \\
ゼオライト 10\%塩水 & $95.9 \pm 1.0$ & $205.0 \pm 7.6$ & $300.9 \pm 7.7 \mathrm{a}$ \\
\hline
\end{tabular}

$\mathrm{z}$ 平均 \pm 標準䛊差 $(\mathrm{n}=3)$ ，異符号間には Tukey の方法 $(\mathrm{P}<0.05, \mathrm{n}=3)$ で有意差あり

56\%，造粒ゼオライト 10\%区では 78\%，ゼオライト $10 \%$ 塩水区では $36 \%$ となった。

\section{4. 漬け汁の放射性セシウム濃度}

梅漬け加工後の漬け汁に含まれる放射性セシウム濃度

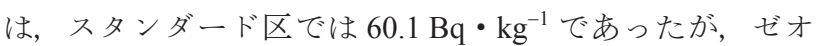
ライトを添加した区ではすべての区でスタンダード区より も放射性セシウム濃度が有意に低くなっていた（第 4 表）. ゼオライト $10 \%$ 区では $33.2 \mathrm{~Bq} \cdot \mathrm{kg}^{-1}$, ゼオライト $20 \%$ 区 では $26.7 \mathrm{~Bq} ・ \mathrm{~kg}^{-1}$ となり， ゼオライトの添加量による有 意差はなかった。 また，造粒ゼオライト $10 \%$ 区では $38.3 \mathrm{~Bq} \cdot \mathrm{kg}^{-1}$ となり，ゼオライト $10 \%$ 区と有意差はなく, ゼオライトの形状による差は確認されなかった。 一方，ゼ オライト $10 \%$ 塩水区では $17.0 \mathrm{~Bq} ・ \mathrm{~kg}^{-1}$ となり，試験区の 中で最も低い值であった. 加工後の漬け汁の放射性セシウ ム濃度は総じて果肉や種と同じ傾向があり, 濃度も果肉に 近い値を示した.

また，スタンダード区の放射性セシウム濃度を $100 \%$ と した場合の各試験区の放射性セシウム濃度比を計算する と，ゼオライト $10 \%$ 区では 55\%，ゼオライト 20\%区では 48\%，造粒ゼオライト 10\%区では 64\%，ゼオライト $10 \%$ 塩水区では $28 \%$ となった。

\section{5. ゼオライトの放射性セシウム濃度}

本研究で用いた処理前のゼオライトの放射性セシウムを 測定したところ，破砕したゼオライトでは $12.3 \mathrm{~Bq} ・ \mathrm{~kg}^{-1}$, 造粒ゼオライトでは $3.8 \mathrm{~Bq} \cdot \mathrm{kg}^{-1}$ の放射性セシウムが検出 された（第 5 表）。この放射性セシウムに関しては，元か ら含まれていたものか，事故後に吸着したものかは明らか ではないが，原料ウメよりも低い濃度であり，実験に影響 を及ぼす濃度ではないと判断した。

梅漬け加工後のゼオライトの放射性セシウム濃度はいず れの区も大幅に高くなっていた。 ゼオライトの添加量を比 較した場合，ゼオライト $10 \%$ 区が $272.1 \mathrm{~Bq} \cdot \mathrm{kg}^{-1}$ ，ゼオラ イト $20 \%$ 区が $175.5 \mathrm{~Bq} \cdot \mathrm{kg}^{-1}$ となり，添加量が多い場合 の放射性セシウム濃度は有意に低かった。 また，造粒ゼ才 ライト $10 \%$ 区は $193.4 \mathrm{~Bq} \cdot \mathrm{kg}^{-1}$ となり，放射性セシウム 濃度はゼオライト $10 \%$ 区よりも有意に低いことが示され た. 一方，ゼオライト $10 \%$ 塩水区では $300.9 \mathrm{~Bq} ・ \mathrm{~kg}^{-1}$ と なり，ゼオライト $10 \%$ 区よりも有意に高かった.

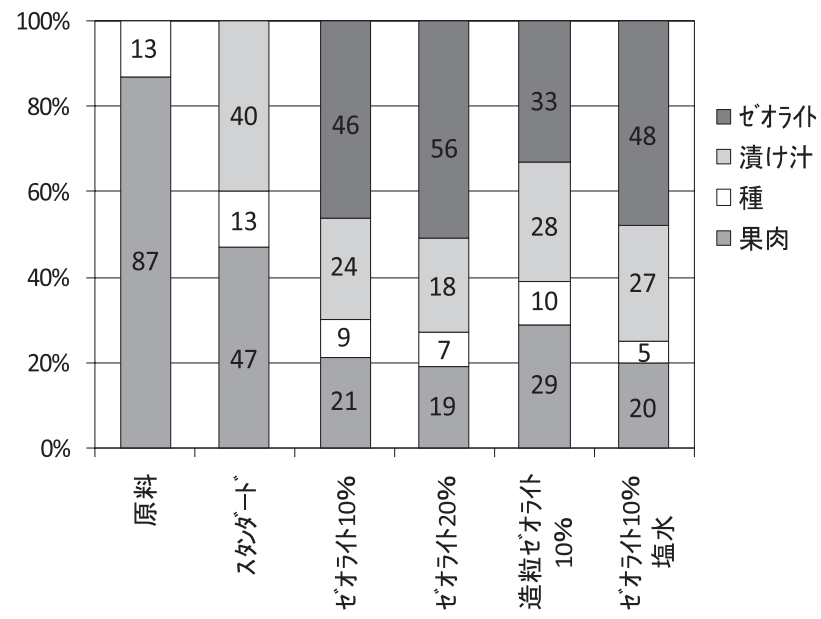

第 1 図 加工後の放射性セシウムの分布割合

\section{6. 加工後の放射性セシウムの分布割合}

加工後の果肉, 種, 漬け汁, ゼオライトについて, それ ぞれの重量と放射性セシウム濃度から放射性セシウム含量 を算出し，放射性セシウムの分布割合を第 1 図に示した. 原料果実では放射性セシウムの $87 \%$ が果肉に含まれてい たが，加工後の果肉に含まれる放射性セシウムは減少し， スタンダード区では 47\%であった. ゼオライトを添加し た区ではさらに減少し，ゼオライト 10\%区では $21 \%$ ，ゼ オライト 20\%区では 19\%，造粒ゼオライト 10\%区では 29\%，ゼオライト 10\%塩水区では 20\%となった。

\section{考察}

加工後の果実重量を比較したところ，ゼオライト $10 \%$ 区，ゼオライト $20 \%$ 区，造粒ゼオライト $10 \%$ 区ではスタ ンダード区よりも10\%前後減少していた. 一方，ゼオラ イト $10 \%$ 塩水区では原料の重量と変わらなかった。 ゼ才 ライト $10 \%$ 区，ゼオライト $20 \%$ 区，造粒ゼオライト $10 \%$ 区では加工時のゼオライトは乾燥した状態であり，加工初 期に滲出してきた果汁をゼオライトが吸収したことが大き く影響していると考光られる。一方，塩水で加工した場合 は, ゼオライトが浸出した果汁を吸収することはないため, 果肉の重量減少が起こらなかったと推察される。また，加 工後のゼオライトの放射性セシウム濃度についてはゼオラ 
イト $10 \%$ 塩水区が最も高いことから, ゼオライトは濡れ た状態で加工に利用しても放射性セシウムの吸着能力を発 揮すると考光られる. このことから，加工時に用いるゼオ ライトは事前に水や塩水を吸収させて敃くことにより果実 の過度な縮小を防ぎながら放射性セシウムを吸収すること ができると考えられる。

放射性セシウム濃度については, ゼオライトの添加量に よって差が出ることを想定していたが，実際にはゼオライ ト 10\%区とゼオライト $20 \%$ 区の果肉や漬け汁の放射性セ シウム濃度に浪とんど差はなく，ゼオライトによる放射性 セシウムの除去には限度がある可能性が示された。 この要 因については本研究のみでは明らかにできないが，梅漬け では大量の食塩を使用して扣り, また, 塩水を用いた加工 ではゼオライト添加量が同じであっても放射性セシウム濃 度はさらに低減していることから，ゼオライトが吸着する 放射性セシウムの量は, 漬计汁中の陽イオンの種類や濃度 などが影響している可能性が考えられる.

また，破砕したゼオライトと造粒したゼオライトで比較し た場合, 破砕したゼオライトの方が放射性セシウムの吸着量 が多かった. ゼオライトによる陽イオンの交換は表面の細孔 に接触することによって起こるため, 液体が接触する面積が 大きい注らが放射性セシウムの吸着量も多くなると考兄られ る.よって, 造粒ゼオライトよりも粒径の小さい, 破砕した ゼオライトのほうが重量当たりの表面積が大きくなり, 放射 性セシウムの吸着効果も大きかったと考えられる.

一方, ゼオライト $10 \%$ 塩水区では果肉の放射性セシウ ム濃度が最も低くなったが，これはゼオライトへの吸着量 が多かったこと以外にも, 加工後の果肉の重量変化がな かったこと, さらに加工中に塩水へ放射性セシウムが流出 したことが大きく影響している。ただし，ゼオライト $10 \%$ 塩水区では, 果肉の放射性セシウム濃度は低いが, 可 食部である果肉の重量は減少していない, そのため, 梅漬 け 1 個当たりの果肉に含まれる放射性セシウム量を算出す ると，10\%添加区や20\%添加区とほぼ同じ量になった。

梅漬け加工に扣いては, 添加する食塩の量や浸漬期間, 調味液などの使用の有無など，実際には条件が異なってく るが，本研究の結果から，加工時にゼオライトを添加する ことによって加工中にゼオライトが放射性セシウムを吸着 し, 加工後の梅漬けの放射性セシウムを低減することがで きることが明らかとなった。

\section{摘 要}

食品添加物として指定されるゼオライトは陽イオン交換 能を有し, 放射性セシウムを吸着することが知られている. 本研究で梅漬け加工時のゼオライト処理による放射性セシ ウムの低減効果を調べた結果, 梅漬けの果肉中の放射性セ シウムはゼオライトを添加することにより低減した。 ゼオ ライトを添加しなかった場合の梅漬けの果肉の放射性セシ ウム濃度を100\%とすると，ゼオライトを10\%添加した場
合の放射性セシウム濃度は 55\%になり，ゼオライトを $20 \%$ 添加した場合は 54\%になった。一方，造粒ゼオライトを 10\%添加した場合は放射性セシウムが $74 \%$ になった。さ らに，塩水を用いて加工した場合，10\%のゼオライトを添 加することにより放射性セシウム濃度は $31 \%$ に低減した。

謝 辞 本研究は, 公益財団法人日本食品化学研究振興 財団の助成を受けて実施しました。 また，本研究の遂行に あたり，ゼオライトを提供して頂いたジークライト株式会 社に深謝いたします。

\section{引用文献}

Goto-Yamamoto, N., K. Koyama, K. H. Tsukamoto, H. Kamigakiuchi, M. Sumihiro, M. Okuda, T. Hashiguchi, K. Matsumaru, H. Sekizawa and H. Shimoi. 2014. Transfer of Cesium and Potassium from Grapes to Wine, Am. J. Enol. Vitic. 65: 143-147.

八戸真弓 - 内藤成弘 ・明石 肇・等々力節子・松倉 潮 川本伸一・濱松潮香. 2014. らどん調理に打ける放射 性セシウムの動態解析, 日本食品科学工学会誌. 61: 34-38.

八戸真弓 ・内藤成弘・佐々木朋子・明石 肇・等々力節子・ 松倉 潮・川本伸一・濱松潮香. 2013. 中華湎の調理 行程に扮ける放射性セシウムの動態解析, 日本食品科 学工学会誌. 60: 54-57.

Kimura, K., H. Kameya, D. Nei, Y. Kakihara, S. Hagiwara, H. Okadome, K. Tanji, S. Todoriki, U. Matsukawa, and S. Kawamoto. 2012. Dynamics of Radioactive Cesium $\left({ }^{134} \mathrm{Cs}\right.$ and ${ }^{137} \mathrm{Cs}$ ) during the Milling of Contaminated Japanese Wheat Cultivars and during the Cooking of Udon Noodles Made from Wheat Flour, Journal of Food Protection 75 1823-1828.

厚生省. 1959. 食品, 添加物等の規格基準（昭和 34 年厚 生省告示第 370 号).

厚生省. 1996. 食品衛生法及び栄養改善法の一部を改正す る法律（平成 7 年法律第 101 号）附則第 2 条第 4 項に 規定する既存添加物名簿 (平成 8 年 4 月 16 日厚生省 告示第 120 号).

厚生労働省. 2013. 食品中の放射性物質の検査 http://www. mhlw.go.jp/shinsai_jouhou/shokuhin.html（平成 26 年 4 月 11 日確認).

鍋師裕美・堤 智昭・蜂須賀暁子・松田りえ子. 2013. 乾 しいたけの水戻し报よび牛肉の加熱調理による放射性 セシウム量の変化. 食品衛生学会雑誌. 54: 65-70

日本原子力学会バックエンド部会. 2011. 福島第一原子力 発電所内污染水処理技術のための基礎データ.

関澤春仁・山下慎司 - 丹治克男 - 大越 聡 - 吉岡邦雄. 2013. リンゴジュースに含まれる放射性セシウムのゼ オライトによる低減，日本食品科学工学会誌. 60: 212217. 
関澤春仁・山下慎司・丹治克男・吉岡邦雄. 2013. 果実の 加工と放射性セシウムの動態, 日本食品科学工学会誌. 60: 718-722.

Tagami, K. and Uchida, S. 2013. Comparison of food processing retention factors of ${ }^{137} \mathrm{Cs}$ and ${ }^{40} \mathrm{~K}$ in vegetables. J. Radioanal. Nucl. Chem. 295: 1627-1634.

高田大輔 - 安永円理子 - 田野井慶太朗 - 中西友子 - 佐々木 治人・大下 誠一. 2012. 放射性降下物に起因した果 樹樹体内放射性核種の分布（第 2 報）—モモ樹体内に 扣ける放射性七シウム含量とその分布について一,

RADIOISOTOPES. 61: 517-521.

高田大輔・安永円理子, 田野井慶太朗, 中西友子, 佐々木
治人，大下誠一２013．放射性降下物に起因した果 樹樹体内放射性核種の分布（第 7 報）—モモ側枝の 放射性セシウム濃度の事故後 2 年間の経時変化一, RADIOISOTOPES. 62: 539-544.

等々力節子・亀谷宏美・内藤成弘・木村啓太郎・根井大介 萩原昌司・柿原芳輝・美濃部彩子・篠田有希・水野亮 子・松倉 潮・川本伸一. 2013. 麦原料から麦茶浸出液 への放射性セシウムの移行率, 日本食品科学工学会誌. 60: 19-22.

財団法人原子力環境整備センター。1994. 環境パラメータ シリーズ 4 食品の調理加工による放射性核種の除去率. 